\title{
Are Vauban's Geometrical Principles Applied in the Petrovaradin Fortress?
}

\author{
Marija Obradović · Slobodan Mišić
}

Published online: 11 September 2014

(C) Kim Williams Books, Turin 2014

\begin{abstract}
There is a widespread opinion in different sources, ranging from popular to scientific, that the project of the Petrovaradin Fortress was conceived under the influence of the most important European military engineer and innovator of the time, Sebastien de Vauban. By examining the historical context as well as by comparing Vauban's geometrical methods for determination of the fortification master line (la ligne magistrale) with Austrian plans and the actual state of the Petrovaradin fortress, especially its Wasserstadt part, we have examined how wellfounded this claim is.
\end{abstract}

Keywords Fortress design · Star-fortress · Vauban · Geometrical construction - Regular polygons · Geometrical analysis · Master line · Petrovaradin Fortress

\section{Introduction}

L'art de fortifier ne consiste pas dans les règles et les systèmes, mais uniquement dans le bon sens et l'expérience (The art of fortifying does not consists in rules and systems, but only in common sense and experience)

Sebastien le Prestre de Vauban (1633-1707)

Controversial data regarding the origin of the Petrovaradin Fortress design and its authorship have surrounded this aspect of the fortress history for many years, ranging from scientific, popular, unofficial and colloquial accounts to legends and

M. Obradović $(\bowtie) \cdot S$. Mišić

Department of Mathematics, Physics and Descriptive Geometry, Faculty of Civil Engineering, University of Belgrade, Bul. kralja Aleksandra 73, 11000 Belgrade, Serbia

e-mail: marijao@grf.bg.ac.rs

S. Mišić

e-mail: slobodan@grf.bg.ac.rs 
myths retold persistently enough to enter even the official sources. There are numerous copies of the plans of the Petrovaradin fortress (over 200 in the Austrian State Archive) based on the built state of works, or done for a particular stage in the reconstruction, but the original conceptual blueprint is unknown. The story of the Petrovaradin Fortress invariably brings up the name of Sebastien le Prestre de Vauban (1633-1707) who gained fame by improving fortification systems and contributed significantly to the development of fortress construction techniques, which remained dominant and admired until the twentieth century.

Vauban's stamp on design of the Petrovaradin Fortress is given varying importance in different sources-from bold claims that the project was his own (Lukić 1992) (a frequent and persistent datum that can be found in most brochures on Petrovaradin and Novi Sad), via official historical sources that his design was developed into detailed plans by several military engineers during Austrian reign (Marković 1984; Gajić 2003) to unfounded, though exciting and compelling accounts in which Austrian engineers (or Prince Eugene of Savoy himself) 'stole' the design from Vauban (Milković 2003). However, whether and to which extent Vauban's doctrine was known and respected can be determined by means of comparative analysis of the design of the fortress and Vauban's geometrical principles. It was our aim to apply these analyses to confirm or reject the claim that Vauban is the actual or conceptual author of this piece of military architecture.

\section{The Petrovaradin Fortress: Position, Function, Significance}

'Gibraltar on the Danube', as the Petrovaradin Fortress is often called, is the largest and best preserved building out of 284 fortifications in Serbia (comprising some forty fortresses and preserved fortified towers and monasteries) (Deroko 1964). Ever since the thirteenth century, it was a strategically important military fortress, which purpose it will serve for the next six centuries. It is situated on the banks of the Danube, on the rock of Petrovaradin (Novi Sad, Serbia) from which it radiates down towards the Pannonian basin. In its current state it is an impressive example of the traditional European style of fortification planning and construction that was dominant in seventeenth and eighteenth centuries and was developed under a resounding influence of the French, Italian and Flemish schools of military architecture. Due to gradual, evolutionary building interventions over a long period of time, the fortress acquired its actual form in the year 1780, which coincides with the end of the reign of Maria Theresa when the last phase of the construction of the complex of buildings on the right bank of the Danube was completed. It was placed under state protection in 1948, and declared a Spatial Cultural-Historical Unit of Great Importance in 1991.

In the second half of the nineteenth century, with the Austro-Hungarian Compromise (1867) and the weakening of the Turkish Empire, the importance of this fortification declined, so that its purpose ceased to be strictly military. In the twentieth century, many military buildings within the fortress became purely 
civilian, housing the Museum of Novi Sad, the Historical Archive, the Academy of Arts with accompanying studios, the Magistrate building, the Planetarium, as well as numerous bars and restaurants. The larger half of the northern complex still serves its military purpose. The Petrovaradin Fortress has recently become popular as the venue of the world-famous EXIT music festival (since 2000), and it is large enough to accommodate eleven separate stages and 200,000 people from all over the world during the four-day event.

\section{The Petrovaradin Fortress Complex}

As can be seen from the copies of the Austro-Hungarian plans ${ }^{1}$ as well as from the Google Earth ${ }^{\circledR}$ satellite pictures, the ground plan of the fortress resembles a comet, with three clearly distinguishable units (Fig. 1):

1. the star-fortress, the last part of the fortress to be completed, also known as the Lower Fortress, or Wasserstadt (Water Town). Wasserstadt comprises one-third of the complex and is the least familiar to the public, since it has been used by the Serbian Army for decades;

2. the body (the oldest part of the fortification, the Upper Fortress);

3. the tail, which has been altered in the meantime-the two-pointed bastion called Hornwerk (Hornwork).

Apart from the main body, the fortress also comprised three parts that no longer exist today:

4. Inzelschanze, the Isle Fortress, which was submerged due to the change of flow of the Danube and construction of the Danube-Tisa-Danube canal;

5. Brückuckschanze, the Bridgehead, on the opposite bank of the Danube;

6. a separate facility comprised of zigzag trenches (Marković 1984), which collapsed after the 1726 earthquake, and were lost when Majur was built (Milkovic 2003).

All parts of the complex are united by the single outer line of defense (envelope) consisting of interconnected fortification-defense system buildings: counterguards, ravelins, lunets and caponiers.

Due to its regular geometrical matrix and clearly identifiable principles of military fortification construction, the Wasserstadt in the north is the most interesting part for the purposes of this paper in terms of geometrical analysis, which is why we will focus on this part of the fortress. Hornwerk, the southstretching tail of the fortification, was the part adapted to the terrain so that it aggressively encroaches upon the plain, thus defending the Upper Fortress on the Rock of Petrovaradin and giving the entire fortress a stable position.

\footnotetext{
1 The maps are used thanks to the kind permission of the Historical Archive of the City of Novi Sad, which keeps the digital record of the plans, transferred from the Archives of Vienna (Österreichisches Staatsarchiv) in cooperation with the City of Novi Sad, in November 2010.
} 

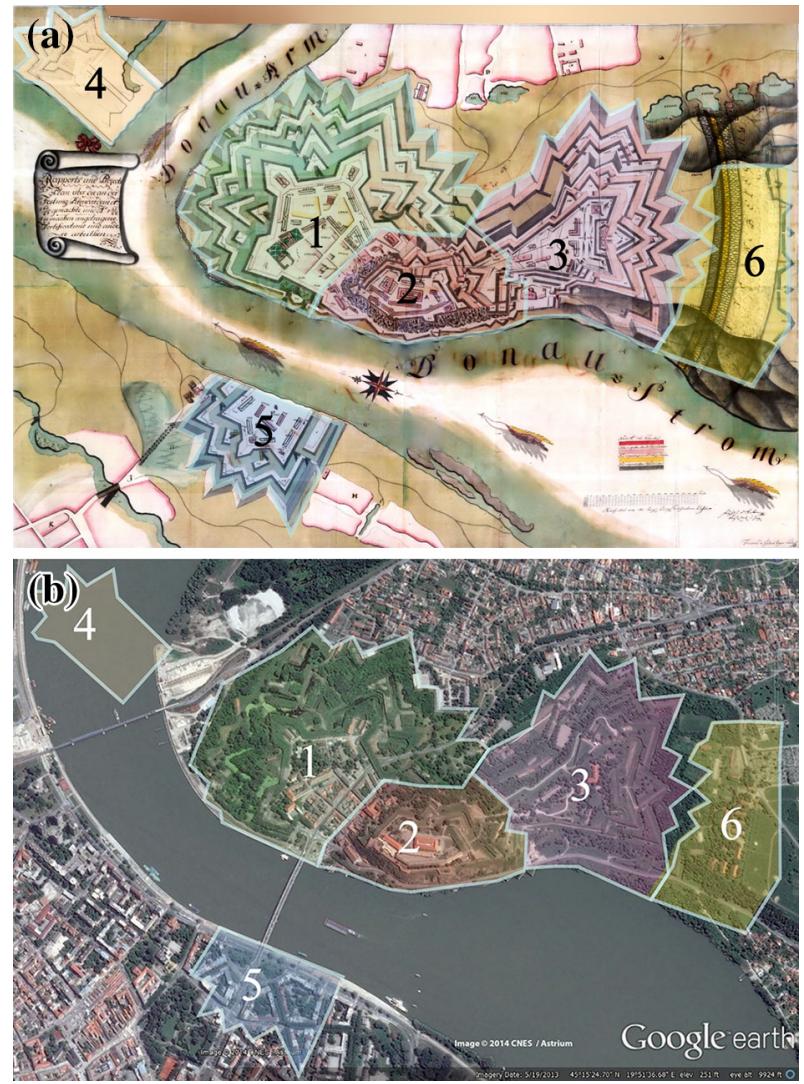

Fig. 1 Zoning of the parts of the Petrovaradin Fortress: a Austro-Hungarian plan from 1762. Image: reproduced by permission, with authors' overlay and mapped onto identical zones (right); b the satellite picture (Google Earth $^{\circledR}$ ) mapped onto identical zones. Image: 2014 CNES/Astrium (Google Earth ${ }^{\circledR}$ ) with authors' overlay

\section{The Early History of the Petrovaradin Fortress}

Continuity of human settlements on the site of the Petrovaradin Fortress stretches from the Middle Palaeolithic era (Mihailović 2009) to the present. In the course of history, up to the seventeenth century, when the current shape of the Fortress started to emerge, different cultures occupied the Petrovaradin area, ranging from the Celts (circa 100 B.C.), through the Romans, who built a fortification named Cusum, the Huns (fifth century), Byzantium (when Petrovaradin, or Petrikon, as it was named at the time, grew further in military and strategic importance), Hungary under Bela IV (eighth century), who allowed Cistercians monks to manage the fortress, to Turkey (late fourteenth through the fifteenth century), after which the Turkish and Hungarian rulers alternated. In one of these periods, Hungarian archbishop Petar Varadi, after whom both the fortress and the locality were named, invested a lot of effort and in 1501 restored the remains of the former fortification, which was recaptured in 1526 by the Turkish army under the command of Suleiman the 
Magnificent. Petrovaradin remained under Turkish rule until 1688, when the army of the Austrian Empire seized the fort. This was followed by deconstruction of the old medieval (Hungarian and Turkish) fortress, while 1692 marked the beginning of the construction of a large, new fortress, designed according to the most modern fortification building system of the time. The foundation stone of the modern Petrovaradin Fortress was laid by the Austrian Duke Croy (Charles Eugen de Croy) in 1692 (Gavanski 1988). It is, therefore, evident that the construction started in Vauban's lifetime, which was most likely enough for certain texts ${ }^{2}$ to identify him as the author of the plans.

\section{Construction of the Petrovaradin Fortress 1692-1780}

The building of the fortress lasted for 88 years, stopping and starting, and spanned the reigns of five Austrian emperors: Leopold I, Joseph I, Charles VI, Maria Theresa and (to some extent) Joseph II. The construction started in the southern side of the Upper Fortress, where the first of many bastions was built upon the orders from the Habsburg emperor Leopold I (the Leopold's Bastion) into which a large amount of material from the medieval fortress was built (Fig. 2a). The work was interrupted in 1694 because of the Turkish army attack. In the same year, the Austrians built the triangular Bridgehead on the other side of the Danube, around which the city of Novi Sad was later built.

After the Karlovac peace treaty in 1699 , the Turks finally left the area, but the Petrovaradin Fortress still kept its strategic importance. In the same year, engineer colonel Count Mathias Keyserfeld made the first blueprint for the fortress, while the next was done by the engineer colonel Count Luigi Ferdinando Marsigli (1659-1730). Engineer colonel Michael Wamberg was in charge of execution and when he died in 1793, engineer colonel Gisenbir succeeded him and remained in charge till 1728 (Marković 1984).

In the relatively calm before 1728 (briefly interrupted by the outbreak of AustroTurkish war between 1716 and 1718, when one of the decisive battles was fought on the very sides of the hill of Petrovaradin under the command of Prince Eugene of Savoy) the construction of the Upper Fortress was continued along with the modifications of the master line, ravelins and counterguards. It was in this period that the Wasserstadt was partially constructed, together with Brückenschanze (the triangular trench of the bridgehead on the left bank of the Danube), the entrenchment of Petrovaradin, quadrilateral fortification, Inselschanze, and finally Hornwerk (the two-horned fortification facing south, the most endangered point). Towards the Danube, in front of the Hornwerk, Kronwerk (Crownwork) was built (Figs. 2b, 3).

The Treaty of Belgrade in 1739 brought a more permanent peace for Austria and Turkey after many decades. The construction of the Petrovaradin Fortress was

\footnotetext{
${ }^{2}$ Truth be told, these are mainly commercial and promotional texts which flooded the news thus leading the public to take this information for granted; but historical publications, as well; see for example (Lukić 1992: 37; Milković 2003: 25).
} 

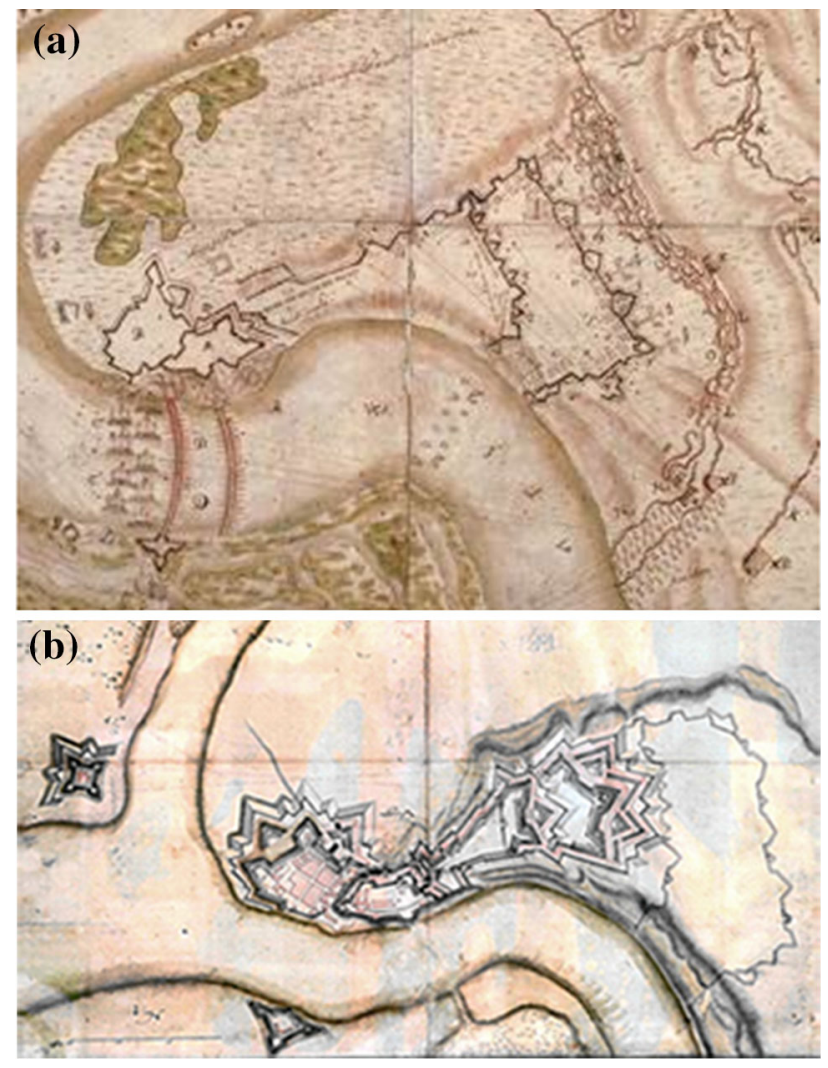

Fig. 2 The old maps of the Petrovaradin Fortress: a the status of works in 1694. Image: public domain (Wikipedia, http://sr.wikipedia.org/wiki/Датотека:1694_m.jpg); b the ground floor plan of the Fortress in the period 1699-1721 with the display of trenches in front of the Hornwerk. Image: reproduced by permission

resumed after nearly three-decade-long interruption (from 1726 to 1753). As can be seen in Fig. 4, many outworks were torn down, so that only the corpus of the fortress delineated by the master line and the several ravelins and counterguards remained.

The final construction phase and the completion of the monumental building started in 1753 and lasted until 1780. Wasserstadt was enlarged to encompass the area of Podgradje (the Lower Town), ${ }^{3}$ stretching to what is today the Gate of Belgrade. Extensive construction work changed not only the appearance of the Wasserstadt, but of the Upper Fortress, Brückenschanze and Hornwerk as well, while the ramparts of Kronwerk were torn down (Fig. 5). Wasserstadt underwent the greatest alterations, receiving a new geometrical matrix, evolving from the

\footnotetext{
${ }^{3}$ The part of Petrovaradin which used to be the core of the fortress complex. As an architectural unit, it has preserved its authentic form and the characteristics of the particular ambience and the spirit of the time in which it was built.
} 


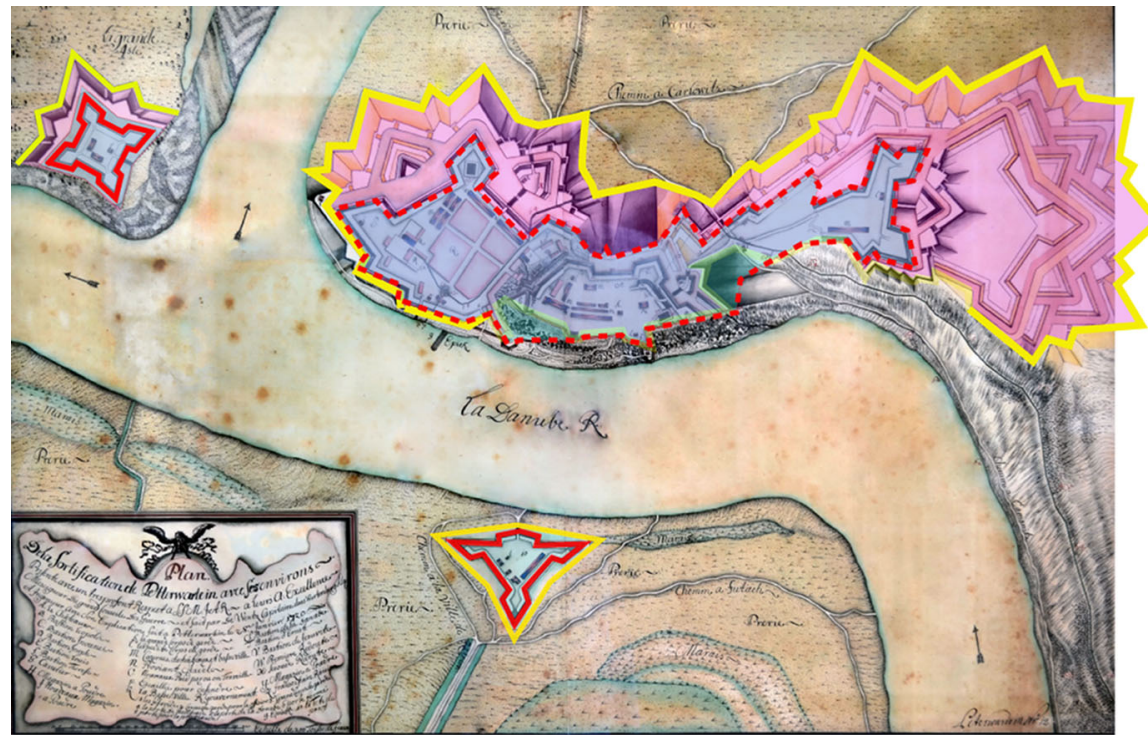

Fig. 3 The Petrovaradin Fortress in 1720. Legend: yellow line contour of the complete fortification with the outworks; shaded pink outworks, which were torn down later; broken red line contours of the fortress walls, master line; solid red line master lines of satellite fortifications on the left Danube bank. Image: reproduced by permission, with authors overlay

initial deltoid shape into a star-like formation based on a pentagonal pattern. The urban matrix formulated in Wasserstadt at the time, has been preserved until today.

At the end of the eighteenth century, battles for this fortification, as well as for the others in the north of the Balkan Peninsula, ceased. When underground corridors and some smaller buildings were finished in 1780, the Fortress acquired its final appearance, which has been preserved till today.

\section{The Principle of Military Fortification Building in Seventeenth and Eighteenth Century}

The need to switch to new form of fortification construction and new geometrical patterns emerged when it became evident that the previous design was deficient in relation to new warfare techniques that used gunpowder. The circular shape of medieval forts proved to be vulnerable to damage caused by cannon fire aimed at vertical walls. Furthermore, if troops managed to reach the ramparts, they threatened the fort from the safety of the 'dead ground', as the defenders could not aim from the surrounding parapets due to blind spots (Bevilacqua 2007).

In contrast, the new type of fortification had a pointed form which resulted from geometrically calculated distribution of a series of arrow-shaped bastions (often taking the form of a star, Fig. 6), specially designed to cover both each other and the trench in front. In order to withstand cannon balls, defensive ramparts were made thicker and lower. Although this facilitated climbing up the walls, the trench itself 


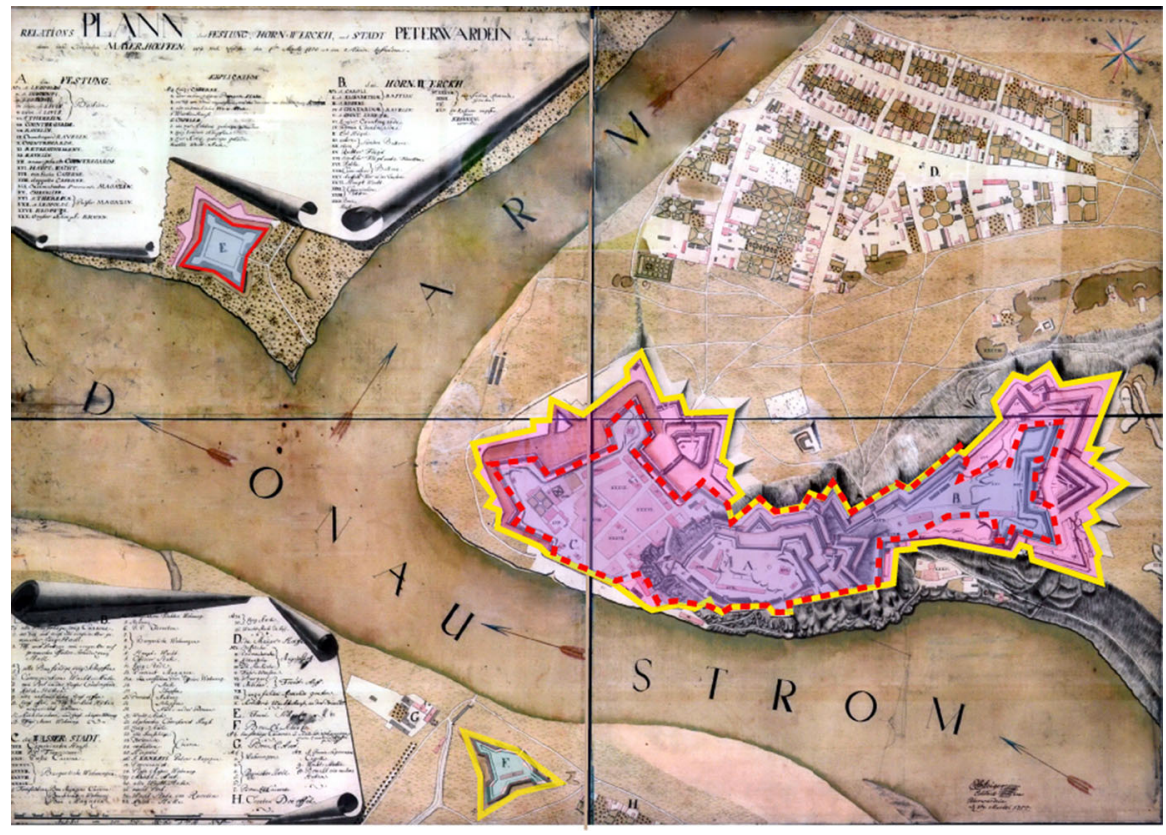

Fig. 4 The Petrovaradin Fortress in 1750: yellow line contour of the complete fortification with the outworks; shaded pink outworks, which were torn down later; broken red line contours of the former master line; solid blue line contours of the master line of the newly constructed fortification. Image: reproduced by permission, with authors overlay

was widened, so that the attacking infantry was still under fire from several positions including the side bastions. The exterior side of the trench was usually characterized by a slight glacis in order to deflect cannon balls aimed at the lower part of the main wall (curtain). Onto the basic body of the fortress different works were still being added, such as ravelins, arrow-like triangular fortifications (detached from the fortress itself), tenailles, which were detached as well, and positioned just outside the curtain, two-pointed formations without the bastion, hornworks, three-pointed formations with the bastion, crownworks, even detached fortresses, added as outworks to protect the main wall from gunfire and provide additional defense positions (Holmes 2004).

In this way, many various additions to the main corpus of the fortress emerge, with special purposes and equally special terminology: ravelins, redoubts, bonnettes, lunettes, tenailles, tenaillons, counterguards, crownworks, hornworks, curvettes, fausse brayes, scarps, cordons, banquettes, counterscarps (Townshend 2005). Some of these works, present in the Petrovaradin Fortress, are shown on Fig. 7. These constructions were built from different materials, mostly soil, and covered in brick, which does not shatter under cannon fire like stone walls do, but absorbs the impact.

Defense of these fortifications gravitates towards the 'bastion', a four-sided addition to the fortress protruding from the ramparts. On two of its sides, cannons could fire over the glacis onto specially shaped open zones between the fortress and 


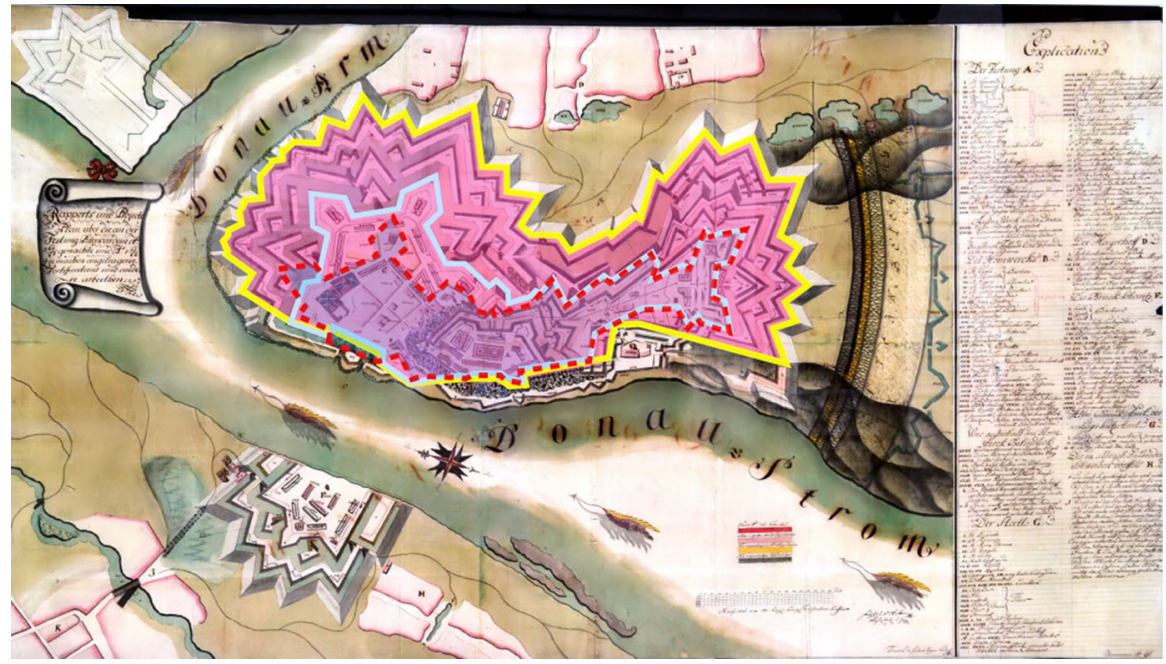

Fig. 5 The new shape of the master line and the outworks in the plan of Petrovaradin Fortress 1760-1762. Yellow line contour of the complete fortification with the outworks; shaded pink outworks, which were torn down later; broken red line contours of the former master line; solid blue line contours of the master line of the newly constructed fortification. Image: reproduced by permission, with authors overlay

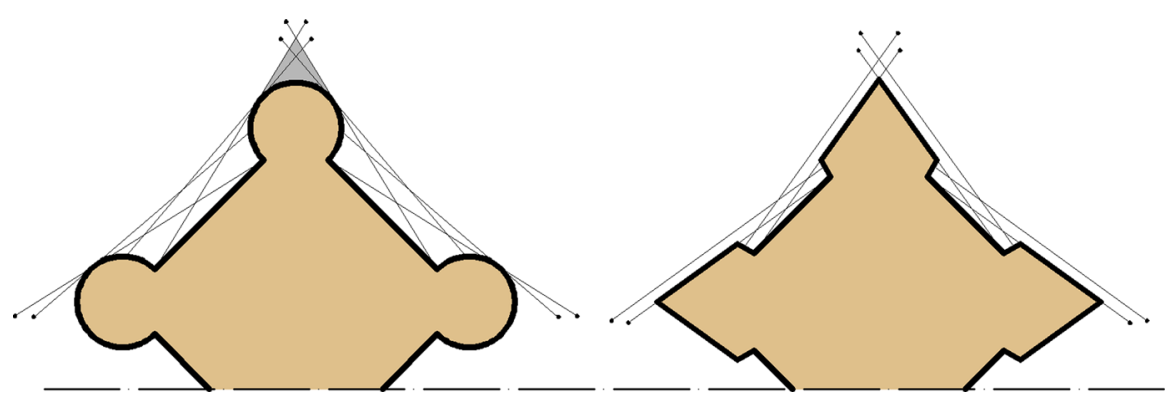

Fig. 6 Comparison of lines of fine in a medieval castle with circular towers and a plan with pointed bastions. Image: authors, after (Duffy 1996: 10)

the surrounding area, so that cannons from the sides of the bastion could neutralize the frontal attack by enfilade. The bastions were placed at the angles of the fort in such a way that the defenders could cover all the fortification walls stretching to the next bastion, including the bastion itself. The number and design of the bastions varies depending on the shape and size of the fortification. The most common shape of smaller fortifications and separated citadels is that of a pentagram. In larger fortified towns the military engineer planned the position and shape of each bastion by using geometrical calculations (De Ville De Ville 1641; Du Fay 1691; Marolois 1627; Pagan 1668).

Between the bastions stretched the curtain, the main fortress wall. Just like the bastion, it had a thoughtfully designed profile that prevented the attacker from 


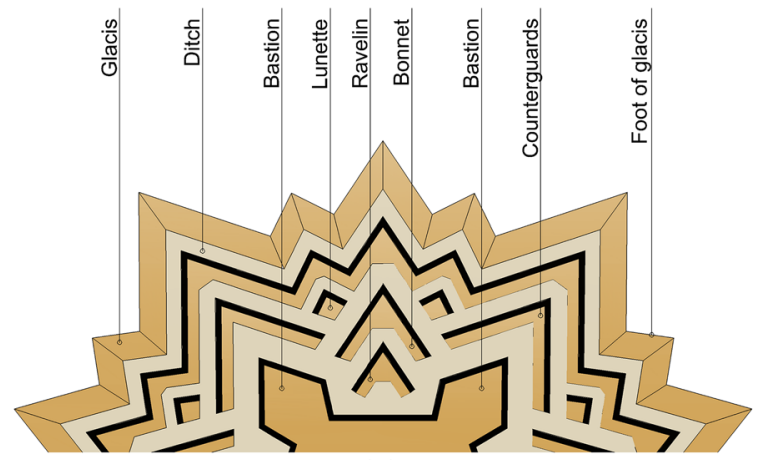

(a)

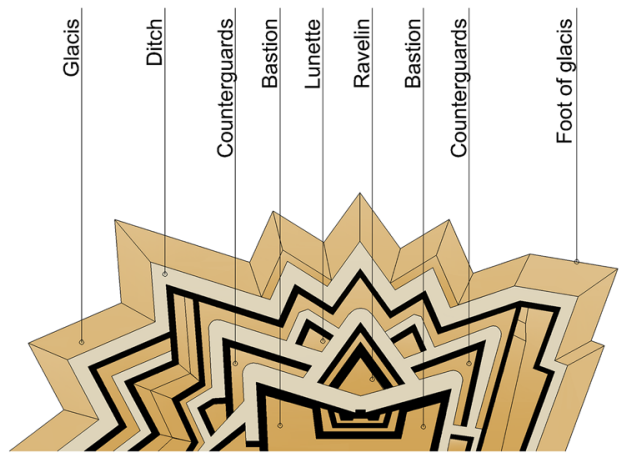

(b)

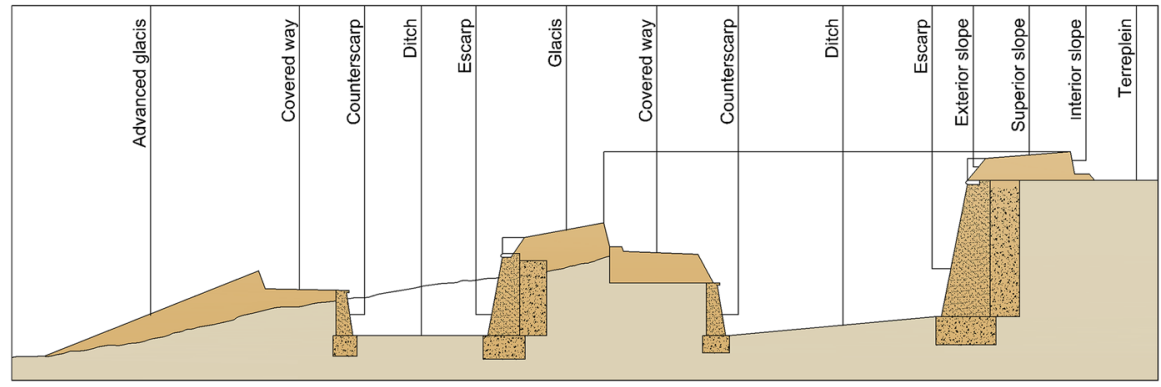

(c)

Fig. 7 The terms for particular works on the fortification, drawn according to the 1764 Petrovaradin Fortress plan: a detail of the Wasserstadt; $\mathbf{b}$ detail of the Hornwerk segment (shown in Fig. 5); c segment of the cross section of the Petrovaradin Fortress illustrating the terms for particular works on the fortification. The drawing is based on the cross section shown on the 1720 plan of the Petrovaradin Fortress. Images: Authors

damaging the material it was built from. From the attacker's point of view, only the ramparts above the glacis were visible. The glacis side facing the fortress ended in a palisade which protected the covered road, along which the defenders could move, and then fell steeply into a deep wide entrenchment which could, for purposes of additional defense, be filled with water (Holmes et al. 2004). 


\section{Star Fortresses: An Example of Regular Polygonal Construction Pattern}

The radial distribution of the bastions according to a regular geometrical pattern resulted in the star-shaped fortification, star fortress or trace italienne, which emerged in the middle of the fifteenth century in Italy with the transition to angular fortification forms, as mentioned. The model of a regular polygon was ancestral from the Renaissance period and Utopian 'ideal city', the project of urban settlement that was based upon the abstract principles and regular geometrical schemes. The idea of utopian cities had existed almost as long as cities themselves, and many of them reflected the aspirations for political reforms and social reorganization, suggesting by its perfect geometrical form the values they pursued. Similar concepts can be identified in various epochs, from Plato and his Republic, whose ideal city "was one which mirrored the cosmos, on the one hand, and the individual on the other" (London 2013), to St Augustine, Sir Thomas More, Francis Bacon, Tomasso Campanella, Charles Fourier, James Buckingham, Étienne Cabet and others (Jones 1960). These ideas were raised to the level of principles by the famous Renaissance architect and polymath Leon Battista Alberti, who in his treatise De re aedificatoria developed, starting from Vitruvius's theories, the rules of planning and construction of an ideal city based on proportion, firmitas (solidity), utilitas (functionality) and venustas (beauty).

Using this concept of ideal geometry, the designers of star fortresses developed a regular polygonal urban matrix of an 'ideal city', adding to it the 'halo' in the shape of single (or multiple) star-shaped polygons (most frequently identical, scaled and rotated). The newly obtained star was not the result of the stellation of the initial polygons, but rather a complex polygon created by adding equilateral triangles onto the sides of the basic polygon, which was accompanied by radial distribution of outworks, appropriate number of counterguards, ravelins, redoubts, etc., designed in accordance with the rules of defense and needs of such a fortification. The angular geometry of the bastion fits perfectly into the star-shaped form that enveloped the central polygonal core of the fortification.

Several examples of such fortifications, with regular polygonal matrices, from four to ten-sided, are given in Fig. 8.

Star fortresses were a lasting model, widely used all over Europe in the sixteenth, seventeenth and eighteenth centuries. The largest contributions to improved construction of these fortresses were made in the seventeenth century by Menno van Coehoorn, Blaise François Pagan and especially Sebastien le Prestre de Vauban, one of Louis XIV's military engineers. The star fortress model was predominant until well into the nineteenth century, when the development of the explosive grenade changed the nature of fortification defense. However, in contrast to regular patterns of star fortresses, fortresses whose plans were irregularly shaped were also built, as the plans had to be adjusted to the conditions of a specific terrain. Furthermore, most fortresses were not 'lucky enough' to be built on ideal, flat ground, so that even those which contained a star-shaped citadel within the complex had to be combined with a chain of free-form walls.

The Petrovaradin Fortress, with one part on the rock of Petrovaradin and the other in the plain, in accordance with le bon sens et l'expérience as in the quote 

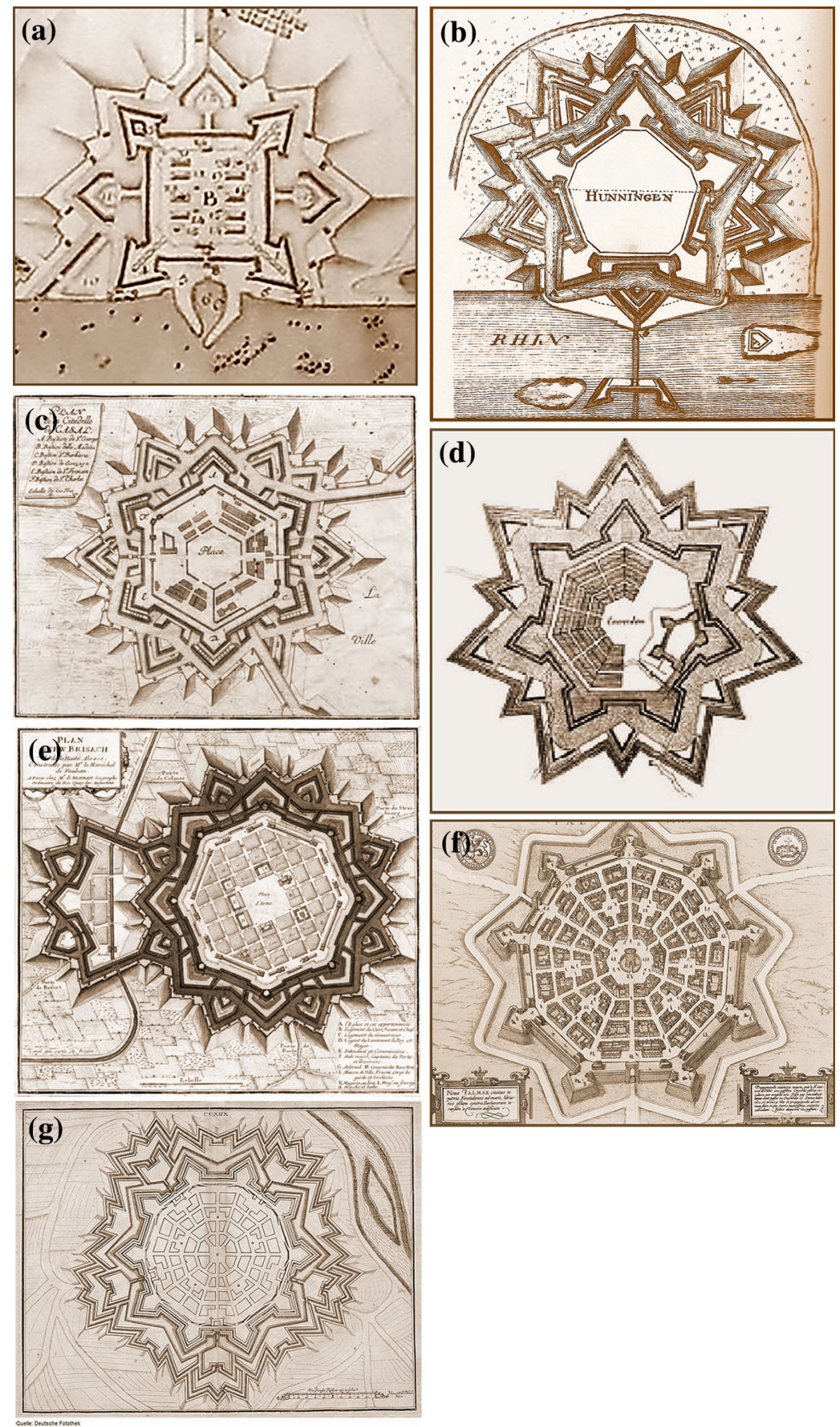
4 Fig. 8 Examples of military fortifications with regular polygon in their bases. a Saint Martin de Re, 17th Century Map, (France) after the fortifications of Vauban, 1722, (Public domain) (http://commons. wikimedia.org/wiki/File:Saint_Martin_de_Re_17th_century_map.jpg); b Fortification of Huningue, France, Author: Sébastien Le Prestre de Vauban (1679-1681) (Public domain) http://en.wikipedia.org/ wiki/File:Fortification_of_Huningue.jpg); c Cascale Monferrato Map, (Italy) Author: unknown (Public domain) (http://commons.wikimedia.org/wiki/File:Casale_Monferrato_map_\%28018_009\%29.jpg); d Fortification plan of Coevorden, Netherlands, Author: Markus Schweiss (Public domain) (http://upload. wikimedia.org/wikipedia/commons/thumb/6/6a/Coevorden.jpg/240px-Coevorden.jpg); e Plan of Citadelle Neuf-Brisach, France, Author: Sébastien Le Prestre de Vauban (Public domain) (http://commons. wikimedia.org/wiki/File:Plan_citadelle_Neuf_Brisach.jpg); f 17th century map of the city of Palmanova, Italy, Author: Unknown (Public Domain) (http://commons.wikimedia.org/wiki/File:Palmanova1600.jpg); g Wilhelm Dilich, copper engraving on paper, 1641. (Peribologia Seu Muniendorum Locorum Ratio Wilhelmi Dilichii) Author: Wilhelm Dilich (Public Domain) (http://commons.wikimedia.org/wiki/File: Fotothek_df_tg_0008838_Architektur_\%5E_Geometrie_\%5E_Festungsbau_\%5E_Hornwerk_\%5E_ Kronwerk.jpg)

from Vauban that opened this paper, is designed and built using a combined system that unites the regular geometry of the star-shaped polygon of the Wasserstadt with the free-form plans of the Upper Fortress and the Hornwerk.

\section{The Principles of Vauban's Military Architecture}

Historically speaking, Sebastien Le Prestre de Vauban (1633-1707) is primarily famous not only as the inventor of skilful and carefully designed siege systems (Ostwals 2006), ${ }^{4}$ but also as one of the most prominent fortification designers, who, thanks to his innovations and the doctrine of construction of effectively defended fortifications, excelled as one of the most significant military engineers of the period (Langinis 2003; Lepage 2009). Apart from introducing some new ideas and variations of the established manner of fortress building, Vauban is considered the first military engineer to have designed a fortress adjusted to the terrain. Respecting the symmetry inspired by classical principles of the aesthetics that governed the fortress design of the time, in the words of Christoper Duffy, "Vauban's fortress stretches over a wavy terrain, encompassing it as though "embracing it" (Duffy 1985: 82-84).

By skilful application of geometrical principles and geometrical constructions, Vauban achieved not only the capacity for effective defense in the fortresses he designed, but a certain artistic quality as well, which most likely was not even deliberate, so that many historians and biographers of today consider him not only an architect, but an artist as well. Thus, the famous architect Jean Nouvel noticed that 'Vauban's fortresses were the early form of land-art and morphing', without (Vauban) being aware of it (Nouvel 2007).

As a student, excelling at mathematics and technical drawing, Vauban was considerably influenced by Rene Descartes, which led him to pay special attention to geometrical principles in fortress design. The procedure which brought him architectural renown strikes a fine balance between linear and nesting geometry (Helie 2009). Although Vauban did not invent the star fortress, he used it widely and

\footnotetext{
${ }^{4}$ These systems introduced circumvallation and contravallation lines, as well as a systematic approach to deployment of parallel trenches in order to capture the enemy's fortress.
} 
developed its form to functional perfection. The improvements he introduced in fortress design were based on several innovations:

1. application of the star-fortress form, whenever the conditions of the terrain allowed it;

2. adjustment of the geometry of the fortress to the terrain;

3. a geometrical approach to positioning and shaping of bastions, which introduced certain changes in the scheme and construction of distances between the primary points of the master line;

4. remodelling the outworks: placing tenailles in front of the curtain, with ravelins and redoubts in front of them;

5. principles of construction and positioning of military facilities within the fortification, among other things suggesting that special purpose facilities (powder magazines, mills, stockrooms) be placed in the heart of the bastion.

\section{Geometrical Principle of Master Line Modelling According to Vauban's System}

As in the work of many other military engineers from the end of sixteenth till the beginning of eighteenth century, such as Jean Errard (cf. 1554-1610) and Blaise François Pagan (1603-1665), Vauban's system of fortification design has geometrical principles of master line formation as its starting point. This regulatory line responds to the outer borders of all the bastion fronts, including all bastions' sides and faces, curtains not excluded. It is defined by the geometry of the bastions, where the face and the side determine the shoulder of the bastion. Between the sides of two neighbouring bastions stretches the curtain, whose regulation line aligns with the sides of the inner polygon, on the vertices of which the gorges of the bastion are situated (Fig. 9a). The master line of regular fortresses must be inscribed in a circle, which is divided by the number of necessary strongholds (bastions), thus providing the vertices of the circumscribed regular polygon of the ground plan and determining the position of the bastions. Vauban defined the rules for determination of linear and angular parameters for circumscribed polygons from tetragon to decagon, not excluding the possibility of creating fortresses on even larger bases, should the need arise (Du Fay 1691).

The radius of the circumcircle drawn around the inner polygon is called the inner radius $\left(\mathrm{R}_{1}\right.$, segment $\mathrm{OP}$ in Fig. $\left.9 \mathrm{~b}\right)$, while the radius of the circumcircle of the outer polygon is called outer radius $\left(\mathrm{R}_{2}\right.$, segment $\mathrm{OQ}$ in Fig. $\left.9 \mathrm{~b}\right)$. The inner radius is part of the outer radius starting from the centre of the polygon $\mathrm{O}$ and ending in the bastion gorge $(\mathrm{P})$. The capital line (la ligne capitale) is the other portion of the outer radius, i.e., the extension of the inner radius starting from the bastion gorge $(\mathrm{P})$ and ending in the vertex of bastion's interior angle (Q).

According to the seventeenth and eighteenth century engineers, the design of the master line is of utmost importance when designing fortifications. Dimensions of the master line elements are dictated by the range of the musket or the arquebus (Jacquot et al. 2011). The line of curtain defense must stretch from the vertex of the 
Fig. 9 a Elements of master line; $\mathbf{b}$ master line of a regular fortification with hexagonal base. Image: authors

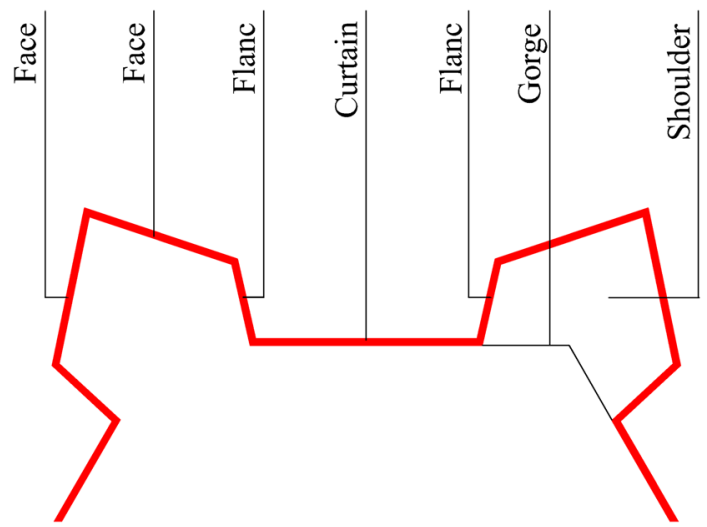

(a)

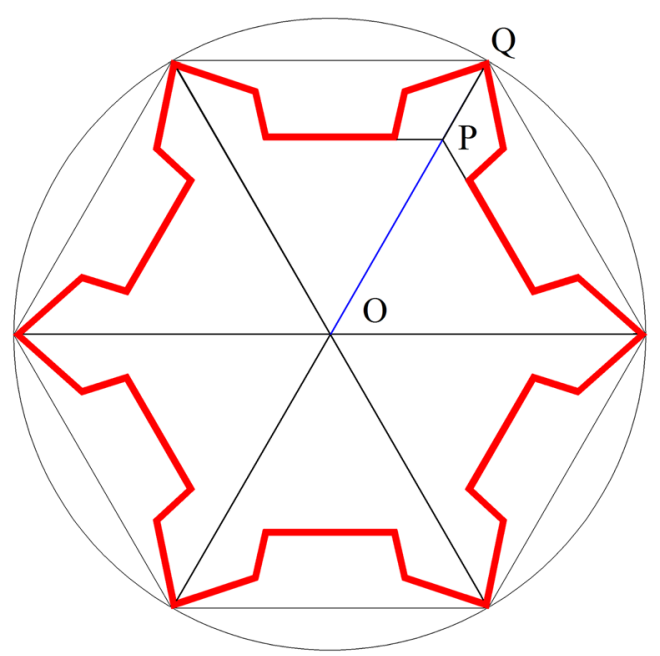

(b)

bastion shoulder (i.e., vertex A of the circumscribed polygon, Fig. 10) to the vertex (N) of the side of the opposite bastion. For the purpose of more effective defense, the shoulder angle can be reduced, so that the line of the bastion face would not match the line of curtain defense.

Vauban's system of tracing the master line is based on thoroughly calculated geometrical construction whose procedure is shown in Fig. 10.

Vauban divides the $\mathrm{AB}$ side of the circumscribed polygon of the master line into eight segments for a square, seven segments for the pentagon and six segments for the hexagon and larger polygons (Du Fay 1691). Thus divided, one segment of the side is transferred onto the perpendicular from the center of the polygon side, thus obtaining segments $\mathrm{AC}$ and $\mathrm{BC}$, which present directions of the lines of defense. The length of the bastion face $(\mathrm{AE}=\mathrm{BF})$ is always $2 / 7$ of the side $\mathrm{AB}$. The 


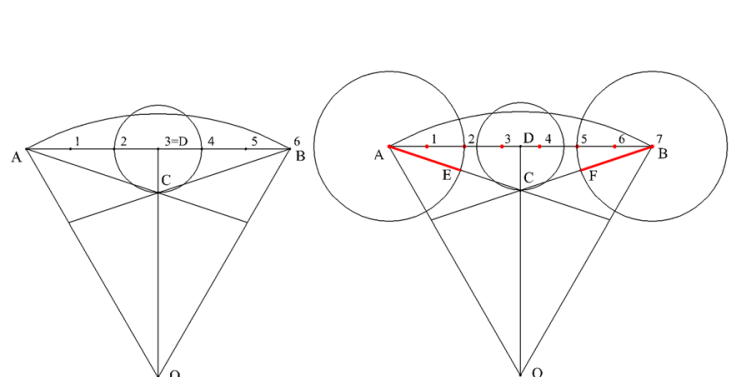

(a)

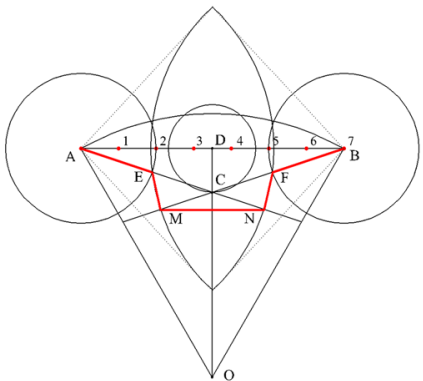

(c)

Fig. 10 Construction of the fragment of master line of fortification with regular hexagonal base according to Vauban's method. Image: authors

intersection of the $\operatorname{arc}(\mathrm{r}=\mathrm{AF}=\mathrm{BF})$ and defense lines gives Vauban in this construction the end points of bastion sides $(\mathrm{EM}=\mathrm{FN})$ and the length of the curtain MN.

In contrast to Vauban, some authors, such as Errard, Pagan, Louis de Cormontaigne (1695-1752), Antoine de Ville (1596-1656), Jacques Ozanam (1640-1717), and Guillaume Le Blond (1704-1781), rely on pre-set dimensions of the elements and master line angles, depending on the size of the base polygon of the fortification (Jacquot et al. 2011; Table 1).

We will single out the method of Vauban's precursor, Pagan, who in Les Fortifications de Monsieur le Comte de Pagan (1668) defines the length of master line segments for three selected groups of fortifications. The classification is based on the length of the side of the initial circumscribed polygon $(A B=200$ toises; $\mathrm{AB}=180$ toises $\mathrm{AB}=160$ toises $){ }^{5}$ The construction of master line fragments according to Pagan's method is shown in Fig. 11.

The beginning of the construction procedure is the same as Vauban's, the segment $\mathrm{DC}$ is a perpendicular from the midpoint of the side $\mathrm{AB}$ of the circumscribed polygon of the fortification base. All the other values are obtained by applying pre-defined values for individual sections of the master line. We should emphasize that in Les fortifications (1668), Pagan suggested the given values for fortifications with pentagonal to dodecagonal bases, paying special attention to square-based fortifications. The suggested values of master line segments are shown in Table 1.

\section{Does Wasserstadt Geometry Reflect Vauban's Principles?}

In the light of the five geometrical principles mentioned above, which can be regarded as the stamp of Vauban's influence, we will analyse one part of the Petrovaradin fortress, Wasserstadt, to determine whether it incorporates or violates these rules.

\footnotetext{
5 One toise was exactly 6 pieds (feet) (about 1.949 m) in France until 1812.
} 
Table 1 Lengths of the master line fragments according to Pagan's method

\begin{tabular}{|c|c|c|c|c|c|c|}
\hline \multirow{2}{*}{$\begin{array}{l}1 \mathrm{t} .=6 \mathrm{p} . \\
=1.949 \mathrm{~m} \\
\mathrm{AB}\end{array}$} & \multicolumn{3}{|l|}{$\mathrm{n}=4$} & \multicolumn{3}{|l|}{$5 \leq \mathrm{n} \leq 12$} \\
\hline & $200 t$ & $180 \mathrm{t}$. & $160 t$ & $200 t$ & $180 \mathrm{t}$. & $160 \mathrm{t}$. \\
\hline $\mathrm{CD}$ & $27 \mathrm{t}$. & $24 \mathrm{t}$. & $21 \mathrm{t}$. & $30 \mathrm{t}$. & $30 \mathrm{t}$. & $30 \mathrm{t}$. \\
\hline $\mathrm{AE}=\mathrm{BF}$ & $60 \mathrm{t}$. & $55 \mathrm{t}$. & $45 \mathrm{t}$. & $60 \mathrm{t}$. & $55 \mathrm{t}$. & $50 \mathrm{t}$. \\
\hline $\mathrm{CM}=\mathrm{CN}$ & $38 \mathrm{t}$. & $33 \mathrm{t}$. & $33 \mathrm{t}$. & $37 \mathrm{t}$. & $32 \mathrm{t}$. & $27 \mathrm{t}$. \\
\hline MN & 73t. and 2p. & 63t. and 4p. & 63t. and $5 \mathrm{p}$. & 70t. and $5 \mathrm{p}$. & 60t. and $4 p$ & $50 \mathrm{t}$. and $4 \mathrm{p}$. \\
\hline $\mathrm{EM}=\mathrm{FN}$ & $22 \mathrm{t}$. & 19t. and $1 \mathrm{p}$. & 18t. and $3 \mathrm{p}$ & 24t. and 2p. & $24 \mathrm{t}$. & $23 \mathrm{t}$ and $2 \mathrm{p}$. \\
\hline $\mathrm{AN}=\mathrm{BM}$ & 141t. and 4p. & 126t. and $1 \mathrm{p}$. & $115 \mathrm{t}$ and $5 \mathrm{p}$. & 141t. and $2 \mathrm{p}$. & 126t. and 5p. & $112 \mathrm{t}$ and $3 \mathrm{p}$ \\
\hline $\begin{array}{l}\text { Angle } \\
\text { ACB }\end{array}$ & $149^{\circ} 6^{\prime}$ & $150^{\circ} 8^{\prime}$ & $150^{\circ} 36^{\prime}$ & $146^{\circ} 36^{\prime}$ & $143^{\circ} 6^{\prime}$ & $138^{\circ} 54^{\prime}$ \\
\hline
\end{tabular}

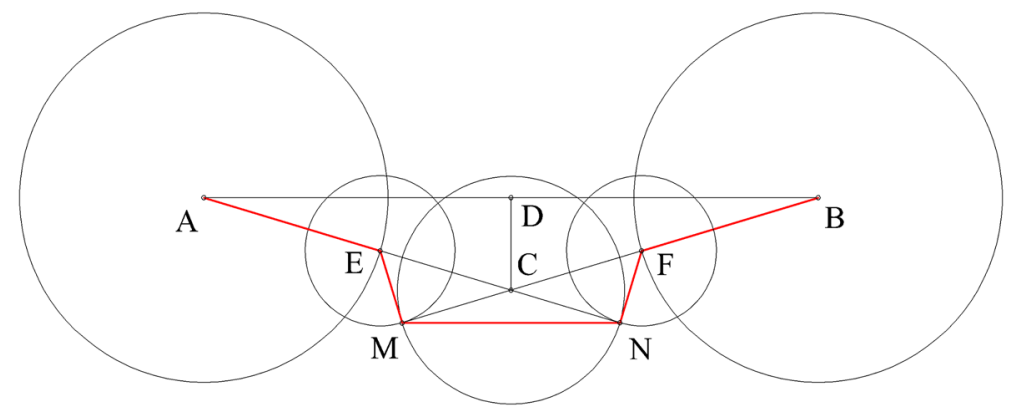

Fig. 11 Construction of master line fragment according to Pagan's method by applying lengths from Table 1. Image: authors

The analysis and reconstruction of the geometrical matrix of the ground plan of the Wasserstadt (using the 1764 plan) accompanied by comparison of these measures and proportions with the satellite pictures (Fig. 12), clearly shows a pentagonal pattern, upon which further modelling of the complex network of outworks is based, forming several five-pointed star-shaped polygons. It is also evident that none of these polygons are either finished or perfectly regular, in spite of the obvious tendency to respect the scheme of the regular polygon. We can see that two (II ${ }^{6}$ and III) out of five vertices of the regular interior pentagon are located exactly in the gorges of the two most protruding bastions, which were most accurately calculated, while bastions I and IV do not follow the identical principle, whereas the bastion $\mathrm{V}$ is partially immersed into the Upper Town platform.

In order to observe the regularities of these polygons more accurately, we have determined the axes of symmetry radiating from the point $\mathrm{O}$, which is the centre of the circumcircle of this regular pentagon, passing the most protruding vertices of the

\footnotetext{
${ }^{6}$ The bastions by number are: I-Bastion Benedicti; II—Bastion Francisci; III—Bastion Maria Theresa; IV-Bastion Joseph; V-Bastion Caroli.
} 

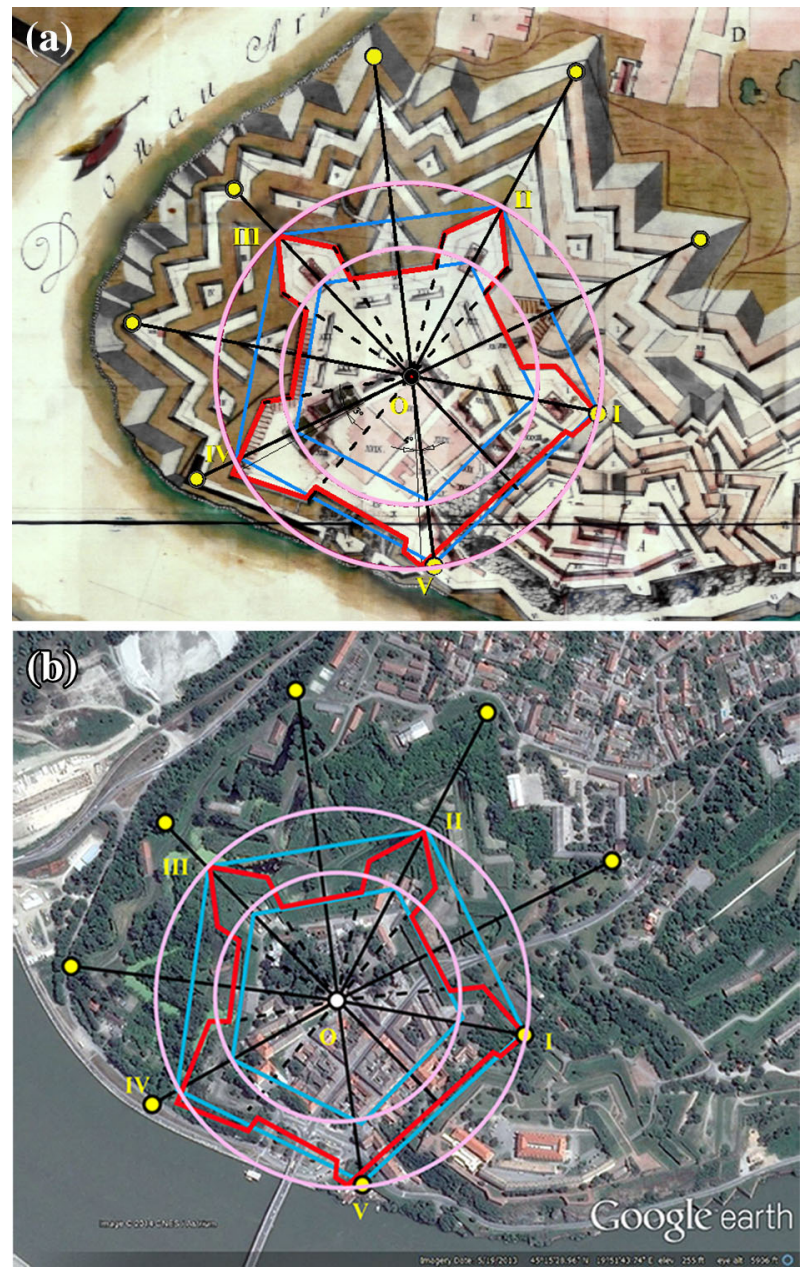

Fig. 12 Geometrical regularities of star fortress observed in Wasserstadt: a, left according to AustroHungarian plan from 1764. Image: reproduced by permission, with authors' overlay; b, right on the satellite image of Petrovaradin. Image: CNES/Astrium 2014 (Google Earth ${ }^{\circledR}$ ), with authors' overlay

bastions (I-V). It is noticeable that the vertices of the counterguards are also aligned along these axes, with certain insignificant aberrations. Similarly, using the most protruding vertices of the bastions II and III we can form the side of the circumscribed pentagon, concentric with the previous one, with (slightly declined) parallel sides. The vertices of bastions I, IV and V respect their positions dictated by the geometry of the pentagon, with smaller aberrations (i.e., IV and V deviate by $3^{\circ}$, and $4^{\circ}$, respectively, while $\mathrm{I}$ is relatively precisely positioned). Separate schematic drawings of the above-mentioned polygons, the Wasserstadt's master line, circumcircles around pentagon and dimensions of these figures ${ }^{7}$ are given in Fig. 13.

\footnotetext{
7 Note: In geometrical drawings certain simplification and idealization of the actual state was made by ignoring and disregarding lesser imprecisions, to obtain a scheme suitable for analysis and observation.
} 
The genesis of the star-shaped polygon, which emerges as a halo around the main ramparts of the fortress (Fig. 14) can be followed in Figs. 15, 16, $17,18$.

By overlapping of obtained star KQLRMSNTPU with the bases of the three pentagonal-based star-shaped citadels designed by Vauban (The Fortress of Lille, Fort Tournai and Fortification of Hunungue, Fig. 19), we have found noticeable aberrations. Since the principle of the master line formation dictated the shape of the ground plan, we observe differences in the shape of the outer star, as well as in the radius of the circle $k^{\prime}$ (in dark blue) on which the vertices of the star are situated. We concluded that there is no necessary match, which suggests that this geometrical principle of outer star formation is not Vauban's pattern.

\section{Analysis of the Geometrical Calculation of the Fragments of Wasserstadt's Master Line}

Proceeding with the examination of geometrical congruencies between master line construction of the Wasserstadt and Vauban's principles, we made a comparison to Vauban's, as well as Pagan's construction (shown in Figs. 20, 21) to determine whether Vauban's construction was the model for the master line between bastions II and III and the Wasserschtadt, or if some other procedures and influences also played their part.

When Vauban's construction is applied, some overlapping between the constructed and the existing bastion faces are observable, but there is also a significant deviation in the position of the curtain line. The surface that demonstrates aberration between the ideal master line according to Vauban and the actual line in Wasserstadt is shown in blue in Fig. 20.

For Pagan's construction, the linear dimensions from Table 1 are adjusted to the actual side length of the circumscribed polygon, which is $333 \mathrm{~m}$ (shown in Table 2). Pagan himself in his Les fortifications recommends proportional scaling of the given linear dimensions of master line segments, depending on the measure by which the actual side of the circumscribed polygon deviates from the dimension given in Table 1.

It was observed that the aberrations (blue surfaces in Fig. 21) of the actual master line of the Wasserstadt, from the line obtained by construction, are in this case significantly smaller, which suggests that military engineers who designed the plan respected the older method of Pagan, or at the very least, that in this segment of the design of Wasserstadt's ground plan Vauban's influence was inessential.

When it comes to the organization of the outworks, Pagan's influence is observable once again, especially considering the fact that counterguards, which are not characteristic of Vauban's method, are present, while characteristic teneilles and redoubts are absent. However, in terms of positioning of military facilities within the master line, echoes of Vauban's doctrine are noticeable, particularly in placement of powder magazines within the bastions.

After all the insights from previous sections, Table 3 shows an overview of principles of Vauban's method present in the Petrovaradin Fortress in order to confirm or reject the hypothesis that he was the author of this fortification. Out of 


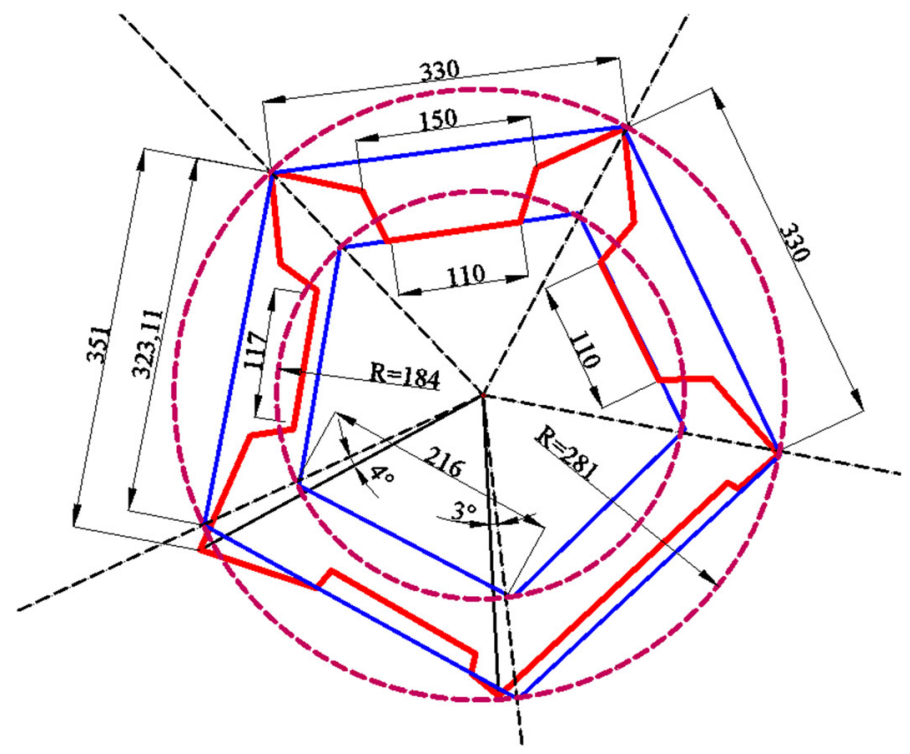

Fig. 13 Inscribed and circumscribed pentagon in the Wasserstadt's ground plan with dimensions and aberrations from the ideal geometrical pattern. Image: authors

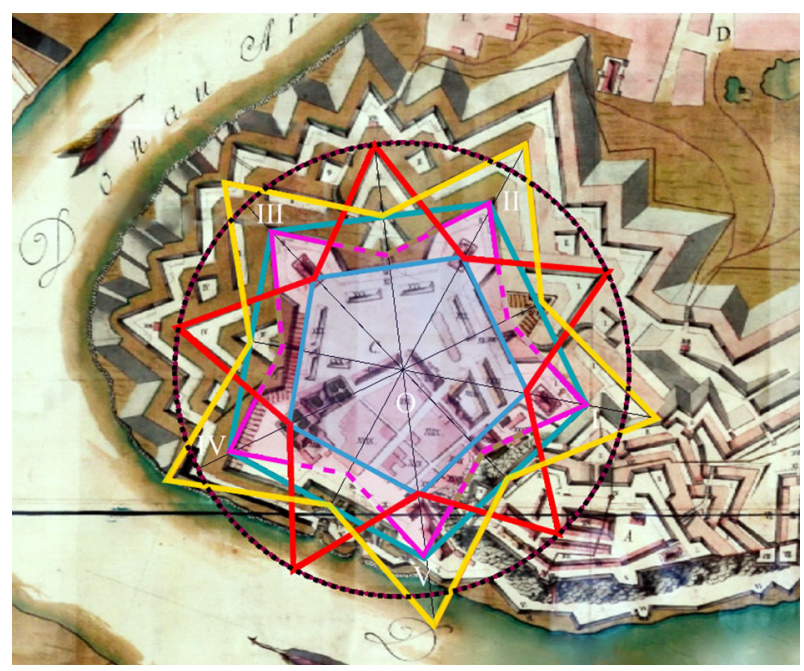

Fig. 14 Star-shaped polygons in the geometry of Wasserstadt's plan. Image: reproduced by permission, with authors' overlay

seven principles we examined, as many as five do not adhere to Vauban's doctrine. In short, the result of the research indicates that Vauban, who is known to have never visited the Petrovaradin Fortress, did not significantly influence the shaping of its ground plan (which may be a disappointment to many tourist guides who eagerly associate the famous name to this building). 


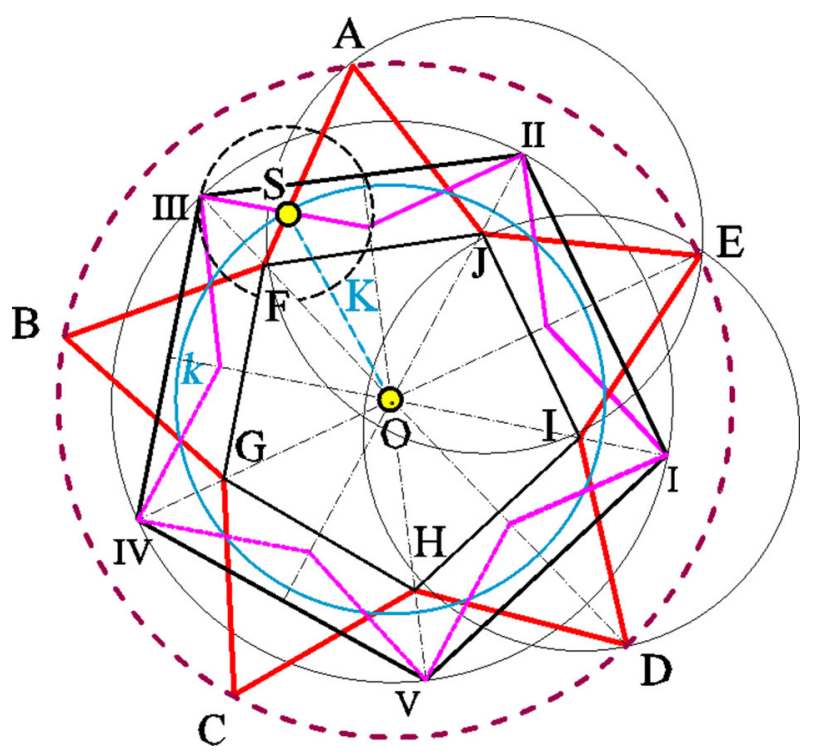

Fig. 15 The initial star AFBGCHDIEJ (in red) is obtained as a complex concave polygon, formed by adding isosceles triangles, approximate to equilateral, onto the pentagon sides. The star $I-I I-I I I-I V-V$ (in pink) is obtained by inscription into the interior pentagon, while its sides are actually lines of defense. The blue circle $(k)$ passes the midpoints of the sides of the star $I-I I-I I I-I V-V$. Image: authors

Fig. 16 When we gyrate (rotate by $\angle 180^{\circ}$ ) the star

$A F B G C H D I E J$, we obtain the star $A^{\prime} F^{\prime} B^{\prime} G^{\prime} C^{\prime} H^{\prime} D^{\prime} I^{\prime} E^{\prime} J^{\prime}$ (broken red line) with interior vertices $F^{\prime} G^{\prime} H^{\prime} I^{\prime} J^{\prime}$. The star $A^{\prime} F^{\prime} B^{\prime} G^{\prime} C^{\prime} H^{\prime} D^{\prime} I^{\prime} E^{\prime} J^{\prime}$ is then scaled by factor $n=K / R_{1}$ (where $K$ is the radius of the circle $k$, and $R_{1}$ is the interior radius) into the star $K Q L R M S N T P U$, so that its interior vertices $Q R S T U$ belong to the circle $k$. Image: authors

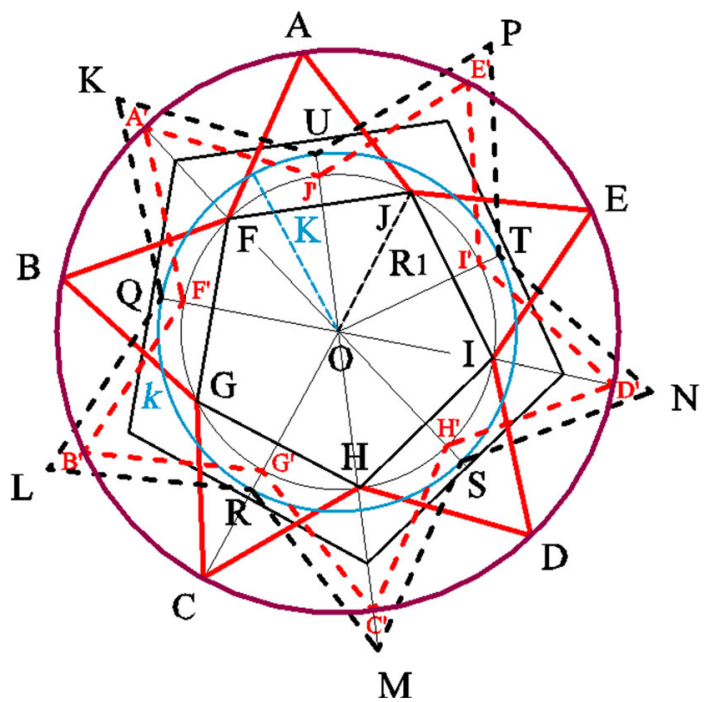

\section{Conclusions}

Analysing the available sources and comparing the geometry of the Wasserstadt of Petrovaradin Fortress to the schemes and principles of Vauban's method, we have 
Fig. 17 Next, interior vertices QRSTU of the newly obtained star are adjusted for the value $m$, so that they are positioned precisely on the interior pentagon sides. The value $m=r_{2}-K$, where $r_{2}$ is the radius of the incircle of the larger pentagon $(I-I I-I I I-I V-V)$. Image: authors
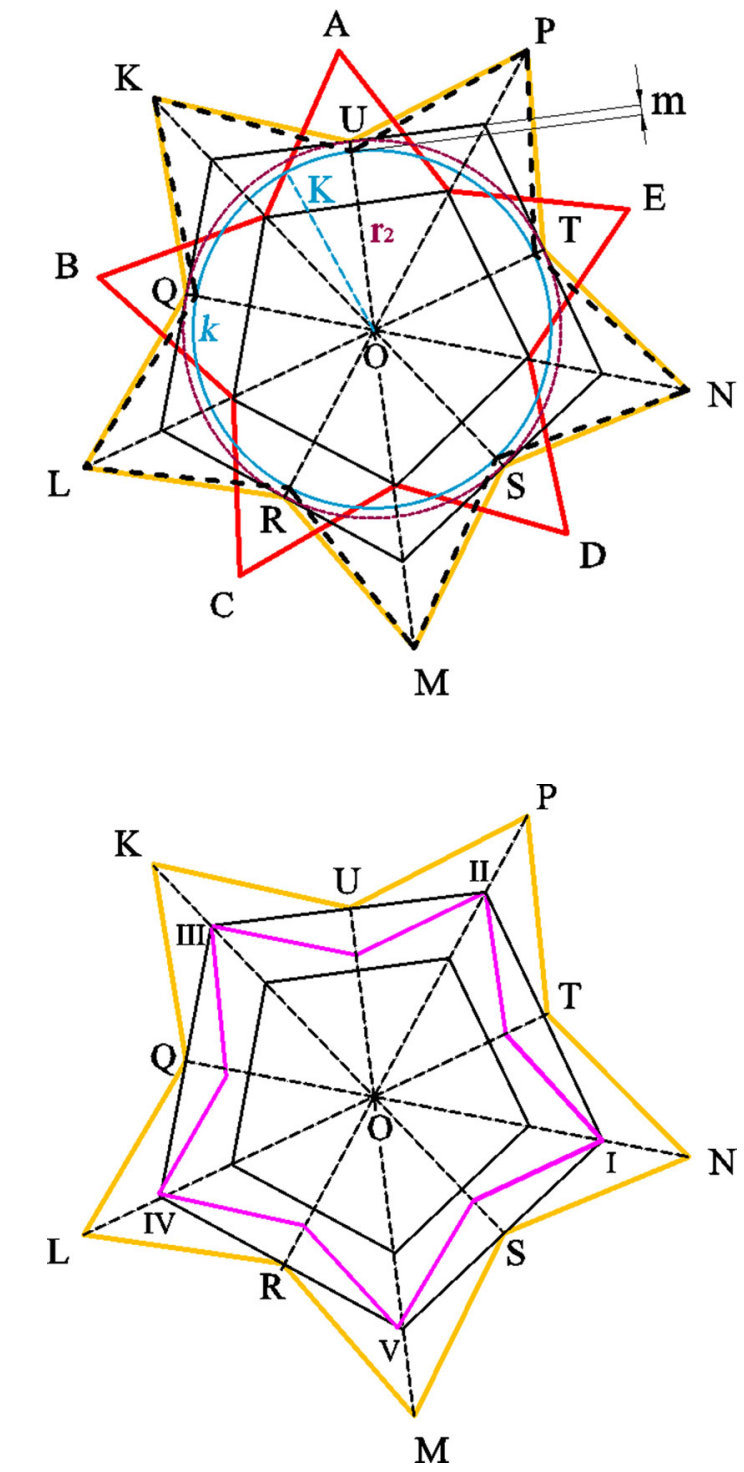

M
Fig. 18 The new star $K Q L R M S N T P U$ (in yellow) exactly matches the star that can be circumscribed around outer counterguards, in ideal draft. In reality, the outworks located in vertices of the star $K Q L R M S N T P U$ had to undergo certain modifications due to proximity of the Danube bank, so that the ideal geometrical matrix in three out of five of the star-shaped polygon vertices was violated. Image: authors

concluded that there is not enough evidence to prove that the great French military architect was the author the project of the Petrovaradin fortress, in facts or in concept, although some influences of his doctrine are noticeable. The design of the fortress, created by the military engineers Keyserfeld, Marsigli, Wamberg, and Gisenbir-all of whom, unfortunately, are less famous than Vauban-is a compilation of various influences, which were modern at the end of the seventeenth into eighteenth and throughout the eighteenth century, having proven effective in the military engineering of Middle Europe. We can say that, as the research has shown, Blaise Pagan, for example, had an equal or even greater influence on the 

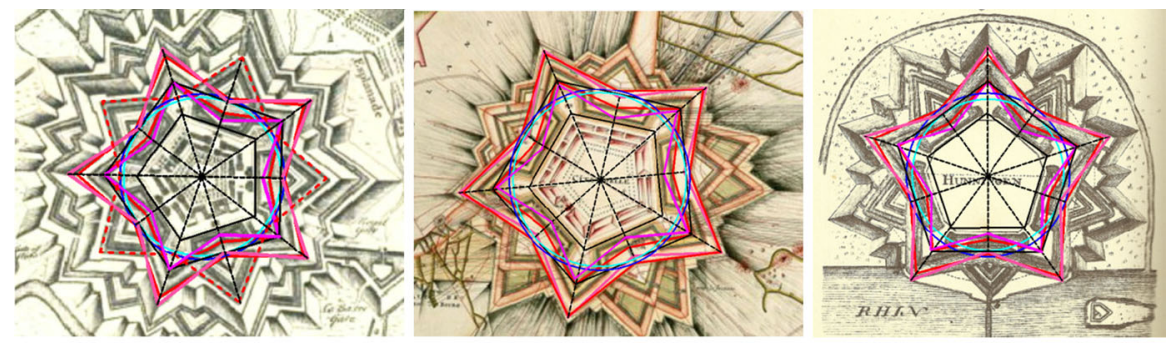

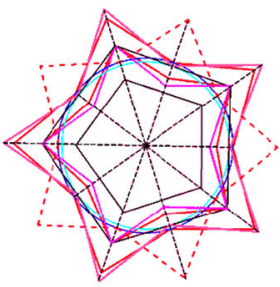

(a)

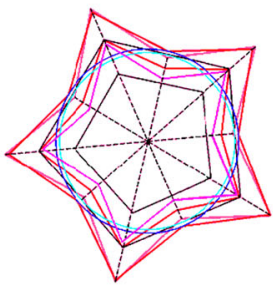

(b)

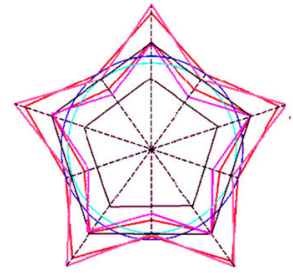

(c)

Fig. 19 Three Vauban's star fortresses and the outer star of Wasserstadt: a Fortress of Lille, Image: Vauban (1633-1707), (public domain), (http://commons.wikimedia.org/wiki/File:Plan_de_Lille_XVIIe_ s.jpg), with authors overlay; b Fort Tournai, 1709 Image provider: Rijksmuseum (public domain), (http:// www.europeana.eu/portal/record/90402/BI_B_FM_075_40.html?start=9\&query=what\%3Atournai\&start Page=1\&qf=YEAR\%3A1709\&rows=24), with authors' overlay; c Fortification of Huningue (Image: Vauban (1633-1707), (public domain), (http://en.wikipedia.org/wiki/File:Fortification_of_Huningue.jpg) with authors' overlay, analysed by overlapping the star matrix from Wasserstadt, and observed aberrations

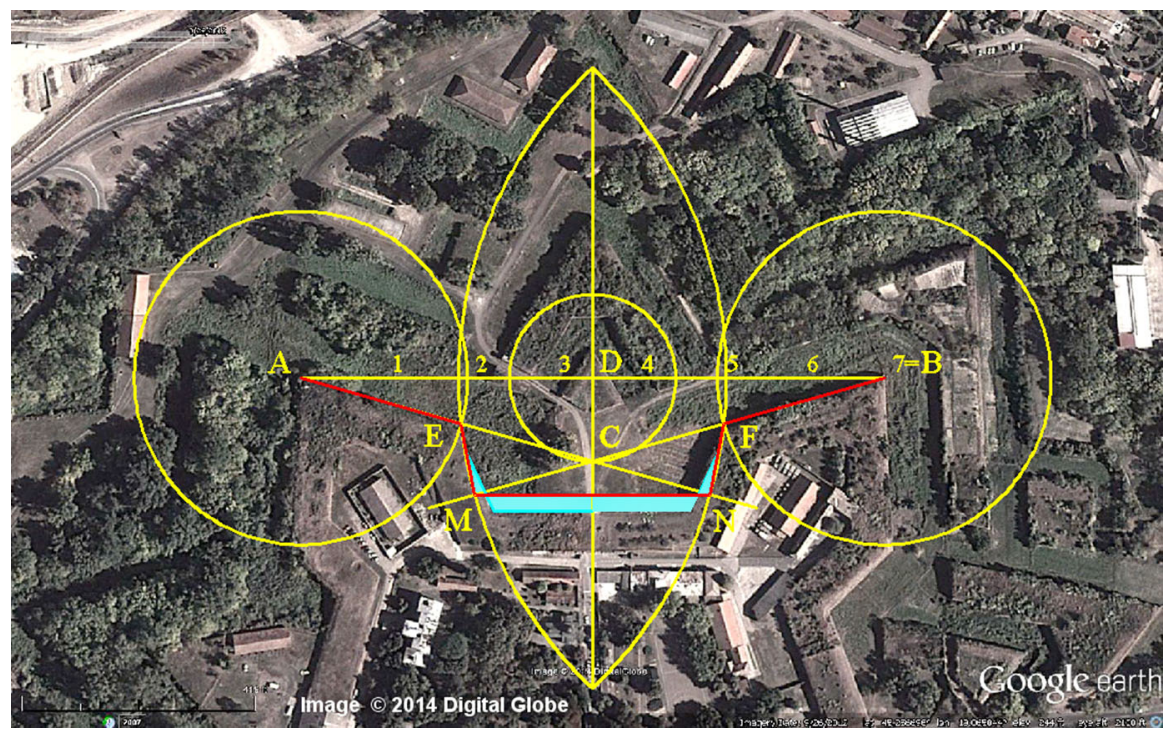

Fig. 20 Vauban's construction. Image: 2014 Digital Globe (Google Earth ${ }^{\circledR}$ ) with authors' overlay 


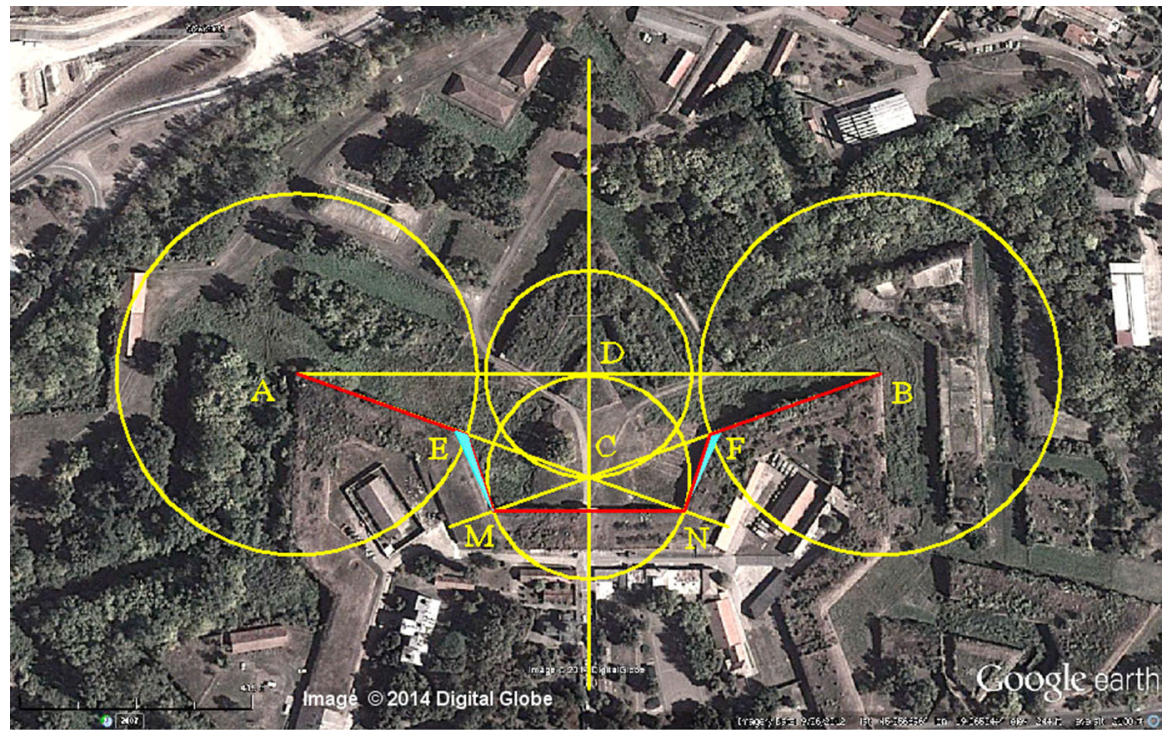

Fig. 21 Pagan's construction. Image: 2014 Digital Globe (Google Earth $\left.{ }^{\circledR}\right)$, with authors' overlay

Table 2 Lengths of the Wasserstadt's master line fragments according to Pagan's method

Table 3 The presence of Vauban's system characteristics in the Petrovaradin Fortress

\begin{tabular}{ll}
\hline & $\mathrm{n}=5$ \\
\hline $\mathrm{AB}$ & $333,00 \mathrm{~m}$ \\
$\mathrm{CD}$ & $58,76 \mathrm{~m}$ \\
$\mathrm{AE}=\mathrm{BF}$ & $102,83 \mathrm{~m}$ \\
$\mathrm{CM}=\mathrm{CN}$ & $57,79 \mathrm{~m}$ \\
$\mathrm{MN}$ & $107,74 \mathrm{~m}$ \\
$\mathrm{EM}=\mathrm{FN}$ & $46,36 \mathrm{~m}$ \\
$\mathrm{AN}=\mathrm{BM}$ & $233,62 \mathrm{~m}$ \\
$\mathrm{Angle} \mathrm{ACB}$ & $141^{\circ}$ \\
\hline
\end{tabular}

Characteristics of Vauban's system

(+) existent

(-) nonexistent

Coincidences of star-patterns

(-)

Adjustment to the terrain

$(+)$

Geometry of master line

(-)

Tenailles

$(-)$

Geometry of Ravelins

$(-)$

Redoubts

(-)

Works within the master line

$(+)$ 
shape and organization of the Petrovaradin Fortress, since the Wasserstadt bastions are constructed in a manner much closer to his principles. Apart from that, the influence of the Renaissance ideal city and the need to adjust to the actual terrain, largely contributed to the form of the ground plan and the overall appearance of the fortress. Although the fact remains that these two characteristics also figure in Vauban's designs, and allowing for the partial influence, it is remarkable that the outworks so characteristic of his work, are absent. To summarize, it cannot be claimed that the project was done by, or even modelled upon Marquis Vauban, since congruencies with his principles and construction doctrine do not prevail. We hope that this paper has shattered some of the persistent myths and brought one of the most freely interpreted chapters in the chronicles of the Petrovaradin Fortress closer to scientific truth.

Acknowledgments The research is supported by Ministry of Science and Education, Republic of Serbia, under the project No. III 44006, "The development of new information-communication technologies, using advanced mathematical methods with applications in medicine, energy, e-governance and the protection of national heritage."

\section{References}

Bevilacqua, Marco G. 2007. The Conception of Ramparts in the Sixteenth Century. Nexus Network Journal 9, 2: 249-261.

Deroko, Aleksandar. 1964. Medieval Castles on the Danube. Belgrade: Turisticka štampa.

De Ville, Antoine. 1641. Les Fortifications du Chevalier Antoine de Ville tholosain, avec L'ataque \& la Defence des Places. Lyon: Chez Philippe Borde.

Du Fay (Abbé). 1691. Manière de fortifier selon la méthode de Monsieur de Vauban avec un traité préliminaire des Principes de Géométrie (2nd enlarged ed.). Paris: La Veuve de Jean-Baptiste I Coignard et Jean-Baptiste Coignard Fils.

Duffy, Christopher. 1985. The fortress in the age of Vauban and Frederick the Great 1660-1789. London: Routledge \& Kegan Paul.

Duffy, Christopher. 1996. Fire \& Stone: The Science of Fortress Warfare, 1660-1860. London: Castle Books.

Gajić, Radenko. 2003. Petrovaradinska tvrđava-Gibraltar na Dunavu. Sremski Karlovci: Kulturni centar Karlovačka umetnička radionica

Gavanski, Djordje. 1988. Petrovaradinska tvrdjava. Novi Sad: Muzej grada Novog Sada.

Helie, Mathieu. 2009. The Genesis of Complex Geometry, Rediscovering Urban Complexity, Emergent Urbanism. http://emergenturbanism.com/2009/06/21/the-genesis-of-complex-geometry.

Holmes, Richard, Charles Singleton, and Spencer Jones. 2004. The Oxford Companion to Military History. Oxford: Oxford University Press.

Jacquot, Kevin, Christine Chevrier, and Gilles Halin. 2011. Study of the Fortification of old scale models in order to automate their 3D modelling. Digital Aids to Design Creativity-eCAADe 29(2011): 967-976.

Jones, Barclay. 1960. Prolegomena to a study of the aesthetic effect of cities. The Journal of Aesthetics and Art Criticism 18(4): 419-429.

Langinis, Janis. 2003. Conserving the enlightenment, french military engineering from Vauban to the revolution. Cambridge: MIT Press.

Lepage, Jean-Denis G. G. 2009. Vauban and the French Military under Louis XIV: An Illustrated History of Fortifications and Strategies. Jonathan's Reviews. Jefferson: McFarland \&Company Inc.

London, Scott. 2013. The ideal city. http://www.scottlondon.com/articles/idealcity.html.

Lukić, Miloš. 1992. Petrovaradin u prošlosti. Novi Sad: Istorijski muzej Vojvodine i Institut za istoriju Marković, Živko. 1984. Novi Sad i Petrovaradin. Novi Sad: Muzej grada Novog Sada.

Marolois, Samuel. 1627. Fortification ou Architecture militaire tant offensive que defensive. Amsterdam: Published by Ian Ianssen. 
Mihailović D. 2009. Middle Palaeolithic Settlement at Petrovaradin Fortress, Petrovaradin Edition, vol. II, Novi Sad: The City Museum of Novi Sad.

Milković, Veljko. 2003. Petrovaradin i Srem-Misterija prošlosti. Novi Sad: Društvo za popularizaciju nauke.

Nouvel, Jean. 2007. Preface. In Vauban l'intelligence du territoire, ed. Martin Barros, Nicole Salat, and Thierry Sarmant. Paris: Chaudun.

Ostwald, Jamel M. 2006. Vauban under siege: engineering efficiency and martial vigor in the war of the Spanish succession. Leiden: Brill.

Pagan, Blaise François de. 1668. Les fortifications de Monsieur le comte de Pagan: avec les theorêmes sur la Fortification. Brussels: François Foppens.

Townshend, Charles. 2005. Oxford history of modern war. Oxford: Oxford University Press.

Marija Obradović associate professor, graduated in Architecture at the University of Belgrade in 1989, and has been employed in Faculty Civil Engineering at the University of Belgrade from 1991, teaching descriptive geometry and computational geometry. She took her Ph.D. in 2006 with a thesis: "Toroidal Deltahedra with Regular Polygonal Bases". She has participated in several Serbian projects dealing with the development of technology and digitizing of national heritage, including the application of geometry and visualization. In addition, she authored over fifty scientific papers published in national and international journals and proceedings of scientific conferences, dealing with various fields of geometry, especially with polyhedral structures in architecture and engineering. She is a member of International Society for Geometry and Graphics (ISGG), and the Serbian Society for Geometry and Graphics (SUGIG), chaired by since June 2014.

Slobodan Mišić assistant professor, graduated in architecture from the University of Belgrade in 1993, and has been employed in the Faculty of Civil Engineering at the University of Belgrade since 1996, teaching descriptive geometry and computational geometry. He took his Ph.D. in 2013 with a thesis entitled "Constructive- geometric Generating of Cupolae with Concave polyhedral Surfaces". He is the author of over twenty scientific papers published in national and international journals and proceedings of scientific conferences. In his scientific research, he is engaged mostly in general collinear planes, constructive geometry and polyhedral structures in architecture and engineering. He is a member of the Serbian Society for Geometry and Graphics (SUGIG). 